\title{
Detection of the Most Common Genetic Causes of Male Infertility by Quantitative Fluorescent (QF)-PCR Analysis
}

\author{
Dijana Plaseska-Karanfilska ${ }^{1}$, Predrag Noveski ${ }^{1}$ and Toso Plaseski ${ }^{2}$ \\ ${ }^{1}$ Macedonian Academy of Sciences and Arts, Research Center for Genetic \\ Engineering and Biotechnology "Georgi D. Efremov", Skopje \\ ${ }^{2}$ Clinic of Endocrinology and Metabolic Disorders, Faculty of Medicine, Skopje \\ Republic of Macedonia
}

\section{Introduction}

Infertility is a major health problem today, affecting about $15 \%$ of couples trying to have a child. Impaired fertility of the male factor is causative in $20 \%$ of infertile couples and contributory in up to another $30-40 \%$. Infertility already affects about $5-7 \%$ of the general male population and may further increase in the future, considering the apparent trend of declining sperm count in industrialized countries. Despite enormous progress in the understanding of human reproductive physiology, the underlying cause of male infertility remains undefined in about $50 \%$ of cases, which are referred to as idiopathic infertility (Ferlin et al., 2006). Most of the idiopathic cases are likely to be of genetic origin because the number of genes involved in human spermatogenesis is probably over thousands. At present, only few of the genes implicated in the processes of testis determination, testis descent and spermatogenesis have routine clinical importance. These include the cystic fibrosis transmembrane conductance regulator (CFTR) gene, whose mutations cause cystic fibrosis and absence of vas deferens and the androgen receptor (AR) gene, whose mutations cause the androgen insensitivity syndrome and spermatogenic damage.

\subsection{Common genetic causes of male infertility}

Chromosomal anomalies and microdeletions of the azoospermia factor (AZF) regions of the $\mathrm{Y}$ chromosome are the only common known genetic causes of spermatogenic failure. The frequency of these two genetic anomalies increases with the severity of the spermatogenic defect, reaching to an overall $30 \%$ (15\% karyotype abnormalities and $15 \%$ of AZF microdeletions) in azoospermic men.

\subsubsection{Sex chromosome aneuploidies}

Sex chromosome aneuploidies, such as 47,XXY (Klinefelter's syndrome), 47,XYY and 46,XX males are the most common chromosome anomalies occurring at birth and in the population of infertile males (Hetch \& Hetch, 1987; Gekas et al., 2001).

Klinefelter's syndrome (KS) is a form of primary testicular failure with testicular hypotrophy and elevated gonadotropin plasma levels, and it represents the most common 
form of male hypogonadism. The prevalence of KS among infertile men is very high, up to $5 \%$ in severe oligozoospermia and 10\% in azoospermia (De Braekeleer \& Dao, 1991). The syndrome usually causes the arrest of spermatogenesis at the primary spermatocyte stage, but occasionally later stages of sperm development are observed. There are two forms of Klinefelter syndrome: nonmosaic, 47,XXY; and mosaic, 47, XXY/ 46, XY. Although previously believed to be sterile, it has been estimated that $25 \%$ of nonmosaic Klinefelter syndrome patients have sperm in their ejaculate (Ferlin et al., 2007). Men with the mosaic form of the disease may have residual spermatogenesis in their seminiferous tubules (Foresta et al., 2005). Klinefelter syndrome patients may try to achieve pregnancy using ICSI, but they risk producing offspring with chromosomal abnormalities (Reubinoff et al., 1998).

The karyotype $47, X Y Y$ is the second most frequent full aneuploidy of sex chromosomes. The spermatogenesis in $X Y Y$ individuals range from severe oligozoospermia to normozoospermia (Skakkebaek et al., 1973; Sharara et al., 1999).

$46, \mathrm{XX}$ chromosomal abnormality is observed mainly in azoospermic males, with frequency of $0.9 \%$ (Mau-Holzmann, 2005). The phenotype is similar to Klinefelter syndrome, but with normal height and unimpaired intelligence. The $S R Y$ gene is present in most of the cases $(S R Y+X X$ males); in these cases males are invariably infertile, and azoospermia results from testicular atrophy. The other category are SRY-XXmales, which assumes a mutation in an autosomal or $X$-linked gene involved in the sex determining cascade which should substitute the SRY, permitting testicular determination in absence of SRY.

\subsubsection{Y chromosome microdeletions}

\subsubsection{Deletions of AZFa, AZFb and AZFc regions}

$\mathrm{Y}$ chromosome microdeletions represent the etiological factor of $10-15 \%$ of idiopathic azoospermia and severe oligozoospermia (Foresta et al., 2000; Ma et al., 2000). In 1976, Tiepolo and Zuffardi provided the first evidence that the long arm of the $\mathrm{Y}$ chromosome is required for fertility in men, when they karyotyped 1170 men and found that six azoospermic men were missing most of the long arm of $\mathrm{Y}$ chromosome (Tiepolo $\mathcal{E}$ Zuffardi, 1976). Subsequently, this cluster on Yq11 became known as the azoospermia factor or AZF. The use of polymerase chain reaction (PCR) of sequence tagged sites (STS) has made possible the detection of small, interstitial deletions invisible by karyotyping (Vollrath et al., 1992). In 1996, the AZF region was subdivided into 25 deletion intervals (D1-D25) and the existence of three non-overlapping subregions, designated AZFa, AZFb and AZFc (Figure 1A), was proposed (Vogt, 1996). Subsequent DNA sequencing approaches revealed eight large palindromic regions containing an array of different ampliconic sequences (KurodaKawaguchi et al., 2001) and demonstrated that these regions harbour a total of 12 different genes/gene families, most of which are exclusively expressed in testises (Kuroda-Kawaguchi et al., 2001; Tilford et al., 2001, Scaletsky et al., 2003). An overlap of 1.5Mb between distal AZFb and proximal AZFc was also demonstrated (Repping et al., 2002). Ampliconic sequences make up almost all of the AZFc sequence and $50 \%$ of the AZFb sequence (Figure 1B).

The frequency of AZF deletions in infertile men ranges in worldwide surveys from 5 to $20 \%$ (Vogt, 1998; Krausz et al., 2003). Y microdeletions are found almost exclusively in patients with azoospermia or severe oligozoospermia (Simoni et al., 1998). The prevalence of $Y$ microdeletions among the infertile males from the Republic of Macedonia is $6.4 \%$, among patients with azoospermia $16.7 \%$ and among those with severe oligozoospermia $2.8 \%$ (Plaseski et al., 2003). Deletions most frequently involve AZFc region, less frequently the 
$\mathrm{AZFb}$ region, and only rarely the AZFa region. The most frequent deletions among Macedonian males are AZFc deletions, while AZFa deletions have not been detected (Plaseski et al., 2006; Plaseski et al., 2008).

\section{AZF locus in Yq11}

\begin{tabular}{|l|l|l|l|l|l|}
\hline Yp11 & & Yq11.21 & Yq11.22 & Yq11.23 & Yq12 \\
\hline
\end{tabular}

A) AZFa AZFb AZFc

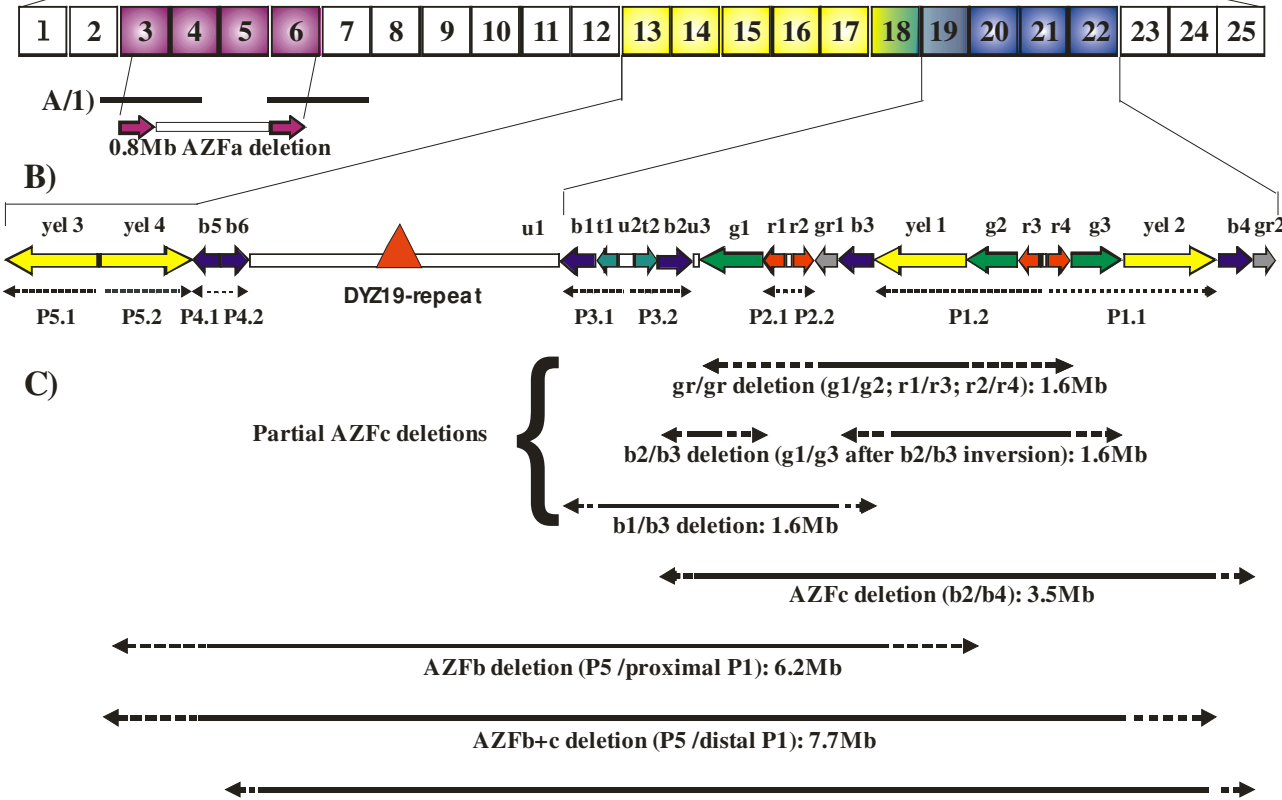

AZFb+c deletion (P4 /distal P1): 7.0Mb

Fig. 1. Schematic view of the AZF locus in Yq1. A) Deletion map of AZF locus: 25 intervals (D1-D25) and three AZF regions (AZFa, AZFb and AZFc). A/1) Complete AZFa deletion, caused by recombination of two homologous HERV 15Yq1/q2 blocks; B) Structural organization of the different amplicons in the AZFb and AZFc regions belonging to five palindromic structures (P1-P5); C) Partial and complete AZFc, AZFb and AZFb+c deletions caused by recombination between different amplicons.

Distant homologous recombination between specific palindromic sequences is believed to be the mechanism for majority Yq deletions (Figure 1C) (Kamp et al., 2000; Repping et al., 2002; Repping et al., 2003), although deletions based on mechanism of nonhomologous recombination were also identified (Costa et al., 2008). The AZFa deletions are located in proximal $\mathrm{Yq}$ and are caused by recombination that take place between retroviral homologous sequences. These deletions account for less then $1 \%$ of all microdeletions of the Y chromosome reported to be associated with spermatogenic failure. Clinically, AZFa deletions are associated with complete absence of germ cells in the testes (Vogt, 2005). Complete deletions of $\mathrm{AZFb}$ have a size of $6.23 \mathrm{Mb}$ and extend within a $1.5 \mathrm{Mb}$ of the 
proximal portion of AZFc. Deletions removing simultaneously part of the AZFb and AZFc regions result from homologous recombination, in which the proximal breakpoints are located in the P5 palindrome and the distal breakpoints mapped in either proximal P1 or distal P1 (Repping et al., 2002). Clinically, complete AZFb deletions are associated with meiotic arrest or Sertoly cell-only syndrome (Ferlin et al., 2003).

The most common AZFc deletion (b2/b4 deletion) eliminates a $3.5 \mathrm{Mb}$ segment that contains 21 genes and is present in about 1 in 4.000 men worldwide (Kuroda-Kawaguchi et al., 2001). Deletions involving the AZFc region account for up to $90 \%$ of all Yq deletions with phenotypes varying from azoospermia to severe oligozoospermia (Reijo et al., 1995, Simoni et al., 1997, Najmabadi et al., 1996) and occasionally to milder oligozoospermia (Oliva et al., 1998). Although natural transmission of $Y$ microdeletions has been reported, majority of the cases arise as a de novo event (Edwards $\mathcal{E}$ Bishop , 1997).

\subsubsection{Partial AZFc deletions}

Partial deletions within the AZFc region (gr/gr and b2/b3) that remove smaller portions of the AZFc region $(1.6$ and $1.8 \mathrm{Mb}$ ) are much more common and are present at various frequencies in different $Y$ haplogroups (Repping et al., 2003; Vogt, 2005). Partial and polymorphic AZF deletions have been also reported in the AZFa (Kamp et al., 2000) and $\mathrm{AZFb}$ regions (Ferlin et al., 2003).

While the association of the complete AZFc deletion with spermatogenic failure is well established, the role of partial AZFc deletions and duplications on spermatogenesis and male infertility is still controversial. With the exception of one study among Han-Chinese population ( $W u$ et al., 2007), all other studies reported no association between the b2/b3 deletion and impaired spermatogenesis. The results of the $\mathrm{gr} / \mathrm{gr}$ deletion are more inconsistent; it is considered a new genetic risk factor by a number of research groups (Kuroda-Kawaguchi et al., 2001; de Llanos et al., 2005; Ferlin et al., 2005; Gianchini et al., 2005, Gianchini et al., 2008), but not by the others (Machev et al., 2004; Hucklenbroich et al., 2005; Ravel et al., 2006; Carvalho et al., 2006; Lardone et al., 2007a; Lin et al., 2007). These contradictory results may in part be due to the methodological differences and differences in the controls (fertile controls, general population, or normozoospermic men).

\subsubsection{AZFc duplications}

In addition to deletions, different duplications at the AZFc region have been reported. Duplications can occur on a chromosome with partial AZFc deletion and generate a chromosome with four DAZ genes, but lacking some STS markers (Repping $S$ et al., 2003; Repping $S$ et al., 2004). Recently, AZFc partial duplication has been shown to be a risk factor for male infertility in Taiwan (Lin et al., 2007). A higher incidence of increased number of DAZ genes was demonstrated in azoospermic and oligozoospermic men in Slovenia (Writzl et al., 2005). Additional studies are needed to determine the role of AZFc partial deletions and duplications in spermatogenesis and male infertility.

\subsubsection{AZF candidate genes}

The AZF regions include genes that are expressed during spermatogenesis and encode proteins necessary for specific stages of spermatogenesis as well as for maintaining the general housekeeping functions of the cells involved (Lahn \& Page, 1997). The Dead box Y (DBY, recently renamed DDX3Y) encodes a putative RNA helicase. The ubiquitin-specific protease 9Y gene (USP9Y, previously known as DFFRY) encodes a protease with activity specific to ubiquitin that is involved in the regulation of protein metabolism (protein turn-over). Both 
genes are located at the AZFa region and have homologous genes on the $\mathrm{X}$ chromosome. The exact role of the candidate genes in the AZFa region are largely unknown, owing to the extreme rarity of naturally occurring, single-gene-specific mutations. Complete deletions of AZFa region is rare, but is well documented and always associated with Sertoli-cell-only syndrome and consequently azoospermia (Ferlin et al., 2007). The translation Initiation Factor $1 \mathrm{~A} \mathrm{Y}$ isoform gene (EIF1AY) and the RNA binding motif (RBM) family are found on AZFb region. EIF1AY encodes an essential translation factor. The PTP-BL-related Y (PRY) family of genes is mapped to $\mathrm{AZFb}$ and $\mathrm{AZF}$ regions and encodes proteins proposed to be involved in apoptosis. RBM and deleted-in-azoospermia (DAZ) genes encode RNA-binding proteins that are exclusively expressed in germ cells. In addition to DAZ, chromodomain Y genes (CDY1) are found on the AZFc region and encode a protein involved in DNA remodeling that can acetylate histone $\mathrm{H} 4$ in vitro. Among other $\mathrm{Y}$ chromosome genes, likely implicated in spermatogenesis but not related to microdeletions, TSPY is a candidate oncogene that, due to its limited expression pattern in germ cells, is thought to function as a proliferation factor during spermatogenesis. The quantities of AZF gene transcripts in testicular tissues of patients with different spermatogenic impairment have been recently examined and an important role of DDX3Y was suggested (Kleiman et al., 2007; Lardone et al., 2007).

\subsubsection{Androgen receptor CAG repeats}

Androgens are essential for male sexual development and for fertility. They act through the AR, which is a transcriptional factor that contains functional domains for DNA binding, ligand binding and transcriptional regulation. The $5^{\prime}$ end of exon 1 of the AR gene includes a polymorphic CAG triplet repeat that codes for a polyglutamine tract. The number of CAG repeats in the normal population varies between 10 and 36. Expansion of the polyglutamine tract to $>38$ repeats in males leads to Kennedy disease [spinal bulbar muscular atrophy (SBMA)] (LaSpada et al., 1991). In addition to neurological symptoms, SBMA patients show signs of hypogonadism, such as gynecomastia, impotence, testicular atrophy and reduced fertility.

In vitro studies have demonstrated a negative correlation between CAG repeat size and AR function (Chamberlain et al., 1994). The possible association of a long CAG repeat with male infertility in Asian populations was suggested because of a four-fold increase in the risk of impaired spermatogenesis in males who had >28 CAG repeats (Tut et al., 1997). Since then, the association of the long CAG repeat number in the AR gene and male infertility has been controversial.

We have also studied the possible effect of long CAG repeat tracts in the AR on infertility among Macedonian men (Plaseski et al., 2007). Our results showed that the mean CAG length dos not differ significantly between males with azoospermia, mild oligozoospermia, severe oligozoospermia, normozoospermia, or known causes of infertility and fertile controls. However, we found a significantly higher percentage of CAG repeats $>26(p=0.022),>27$ $(p=0.018)$ and $>28(p=0.009)$ in males with mild oligozoospermia. Thus, our initial results indicated a possible association between CAG repeat length and mild oligozoospermia.

\section{Screening for the presence of the most common genetic causes by quantitative fluorescent (QF)-PCR}

Screening for chromosomal abnormalities is usually done by cytogenetic analysis and for AZF deletions by PCR analysis of several sequence tagged sites (STSs) in the three AZF 
regions. Recently, we have described a multiplex QF-PCR method that allows simultaneous detection of the most common genetic causes of male infertility, i.e. sex chromosomal aneuploidies and AZFc and AZFb deletions, and some potential risk factors such as partial AZFc deletions/duplications and AR CAG repeats (Plaseski et al., 2008). This 11-plex QFPCR analysis was shown as a rapid, simple, reliable and inexpensive method that can be used as a first-step genetic analysis in infertile patients. Here, we present a modified system, where we have included additional markers in the AZFa and AZFb region, as well as a marker for determination of the $\mathrm{X} /$ chromosome 3 ratio.

\subsection{QF-PCR method}

The quantitative fluorescent $(\mathrm{QF})$ polymerase chain reaction (PCR) included 13 markers: amelogenin gene which is present on $X$ and $Y$ chromosomes and allows for the determination of the $\mathrm{Y} / \mathrm{X}$ ratio (AMEL marker), TAF9B gene that is present on chromosomes $X$ and 3 and permits the determination of $x /$ chr 3 ratio, four polymorphic $X-$ specific short tandem repeat (STR) markers (XHPRT, DXS6803; DXS981 and exon 1 of the AR gene), three non-polymorphic Y-specific markers (SRY gene, sY86 in AZFa and sY134 in $\mathrm{AZFb}$ region), polymorphic Y-specific STR marker (DYS448), and co-amplification of DAZ/DAZL, MYPT2Y/MYPT2 and CDY2/CDY1 fragments that permit determination of the DAZ, MYPT2Y, CDY1 and CDY2 gene copy number. The details of the primers used in the 13-plex QF-PCR are given in Table 1, while the location of the markers on the $Y$ chromosome is given in Figure 2.

The AMEL marker exploits the 6bp deletion on the $X$ chromosome sequence, enabling amplification of specific X-chromosome (106 bp) and Y-chromosome sequences (112 bp). The TAF9B marker co-amplifies a fragment of the TAF9B gene on $\mathrm{X}$ chromosome (144bp) and the one on chromosome $3(140 \mathrm{bp})$. The DAZ gene copy number was quantified using primers that co-amplify a fragment of intron 10 from DAZ gene $(208 \mathrm{bp})$ and from the homologous autosomal locus DAZL on chromosome 3 (211 bp or $251 \mathrm{bp}$ ). The two MYPT2Y copies in the AZFc region were co-amplified with the MYPT2 gene on chromosome 1, giving fragments of $181 \mathrm{bp}$ and $176 \mathrm{bp}$ respectively. The relative ratio of the two CDY1 genes in the $\mathrm{AZFC}$ region and two CDY2 genes in the AZFb region, which share $98 \%$ nucleotide identity was scored by two PCR sets which amplify a $6 \mathrm{bp}$ nucleotide difference in the 5 ' region, producing fragments of $200 \mathrm{bp}$ for CDY1 and $194 \mathrm{bp}$ for CDY2.

One primer in each set was labeled with 6-FAM or HEX fluorescent dye, which allowed the determination of the length of the different STR and STS alleles and for quantification of the relative Amel Y/Amel X, TAF9B-X/TAF9B-chr. 3, DAZ/DAZL, MYPT2Y/MYPT2 and CDY2/CDY1 ratios on ABIPrism 3130 Genetic Analyzer using a GeneMapper Software v.4.0 (Applied Biosystems, Foster City, CA, USA).

The PCR reaction mixture contained PCR buffer (Applied Biosystems), 50-100 ng genomic DNA, $200 \mu \mathrm{M}$ each of the four dNTP's (dATP, dCTP, dGTP and dTTP), 2-8 pmol each of the primers, and 1.5U TaqGold polymerase (Applied Biosystems) in a total volume of $15 \mu \mathrm{l}$. The PCR was performed under the following conditions: initial denaturation step at $95^{\circ} \mathrm{C}$ for 5 minutes, followed by 28 cycles of 1 minute denaturation at $95^{\circ} \mathrm{C}, 1$ minute annealing at $58^{\circ} \mathrm{C}$ and 1.5 minutes elongation at $72^{\circ} \mathrm{C}$; and final elongation at $72^{\circ} \mathrm{C}$ for 30 minutes.

\subsection{QF-PCR results}

The normal results of the 13 markers included in the QF-PCR analysis in males without sex chromosome aneuploidies and AZF rearrangements are shown in Table 2 and Figure 3. The 


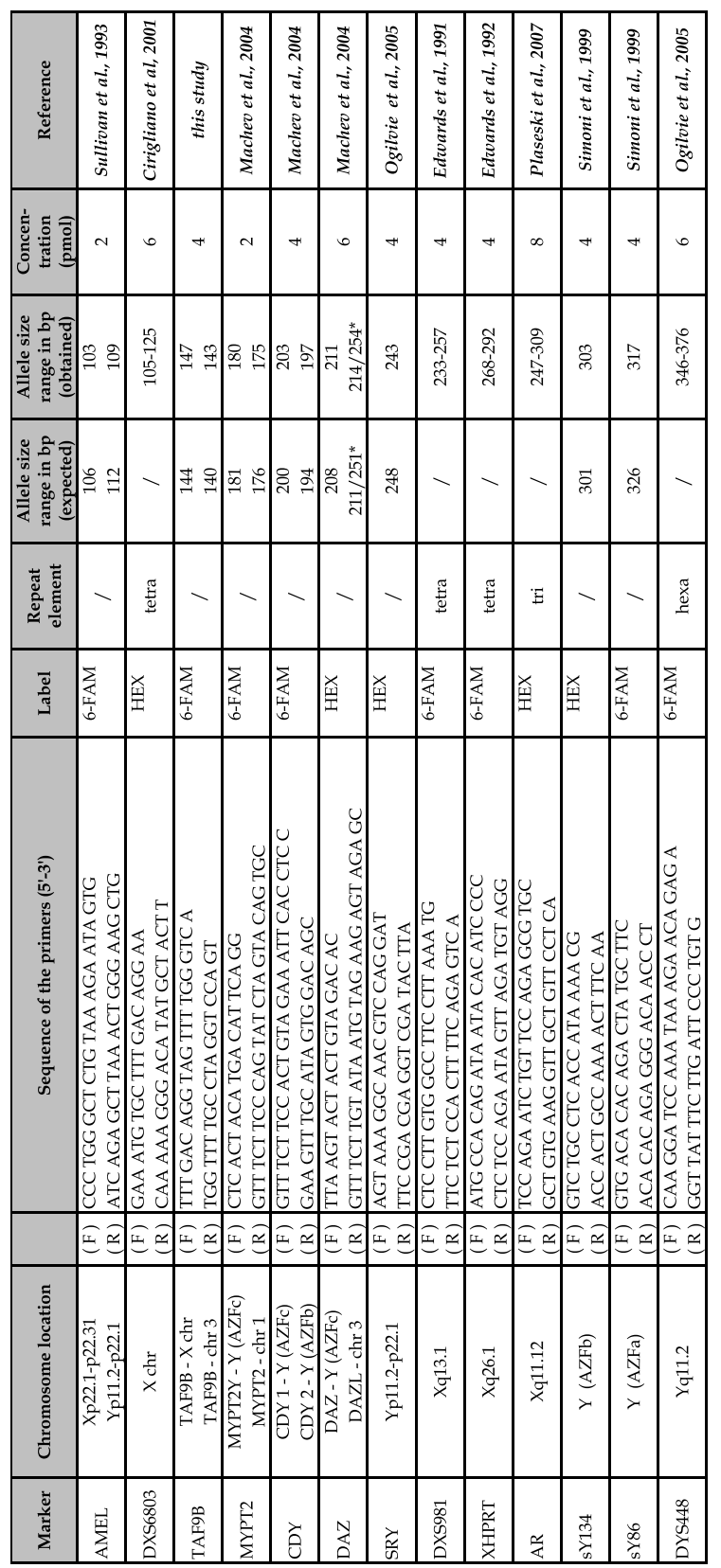

* in app. $25 \%$ of individuals a $40 \mathrm{bp}$ insertion polymorphism in DAZL intron 10 is present (Machev et al., 2004)

Table 1. Details of the primers used in the QF-PCR for the detection of the most common causes of male infertility 


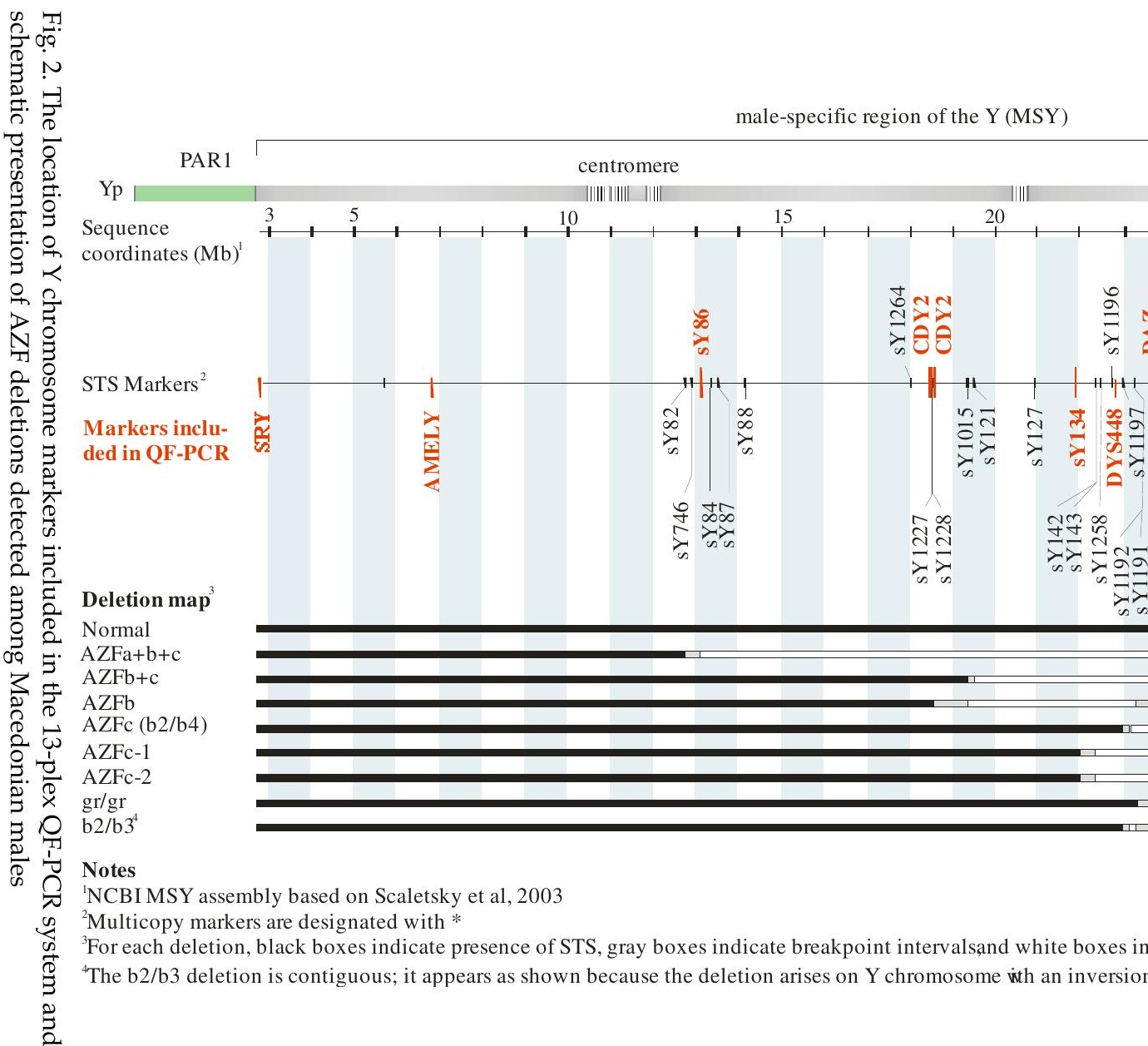




\begin{tabular}{|c|c|c|c|c|c|c|c|c|c|c|c|}
\hline & స్తి & 㞼 & 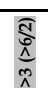 & 烝 & 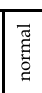 & 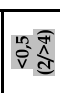 & $\begin{array}{l}\overline{\widetilde{\Xi}} \\
\stackrel{\Xi}{\sigma}\end{array}$ & 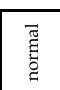 & $\begin{array}{l}\widetilde{\widetilde{g}} \\
\stackrel{్}{0}\end{array}$ & 急 & 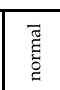 \\
\hline $\mathbb{2}$ & 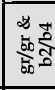 & 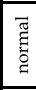 & 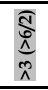 & 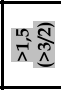 & 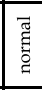 & in & 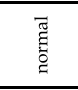 & 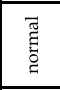 & 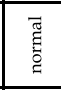 & 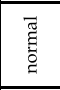 & 襜 \\
\hline & 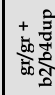 & 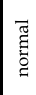 & $\sqrt{\pi}$ & 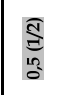 & 氶 & న్ & 㞼 & 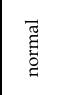 & 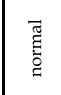 & 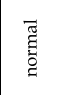 & 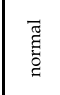 \\
\hline \ّ & 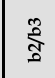 & 㞼 & $\frac{\mathrm{d}}{\mathrm{d}}$ & 呇 & 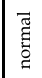 & త్d & 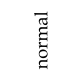 & 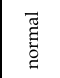 & 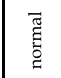 & 呇 & 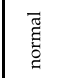 \\
\hline స & $\frac{\frac{50}{b}}{\frac{5}{b}}$ & 丞 & d్d & $\begin{array}{l}\overline{\mathbb{S}} \\
\text { da․ }\end{array}$ & 焉 & 점 & 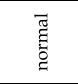 & 节 & 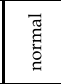 & 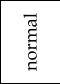 & 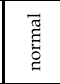 \\
\hline & 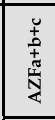 & $\vec{v}$ & $\begin{array}{l}\text { U̦ } \\
\text { å }\end{array}$ & 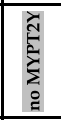 & 丞 & 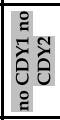 & 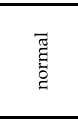 & 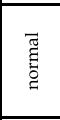 & 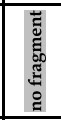 & 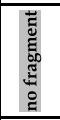 & 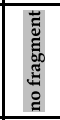 \\
\hline & 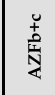 & $\bar{v}$ & 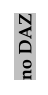 & : & 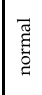 & 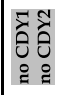 & 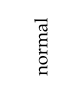 & 丞 & ๕ & 㞼 & ๕ \\
\hline 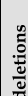 & 通 & 㞼 & $\begin{array}{l}\text { 점 } \\
\text { D. } \\
\text { : }\end{array}$ & 呇 & 氶 & $\begin{array}{l}\mathbb{S} \\
\text { 경 }\end{array}$ & 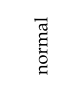 & 褅 & ๕ & 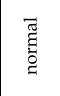 & : \\
\hline ষ্ & 苋 & 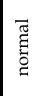 & 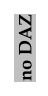 & 율 & 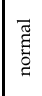 & $\begin{array}{l}\overline{0} \\
\text { : } \\
\text { : }\end{array}$ & 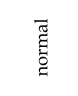 & 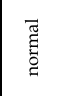 & 㞼 & $\begin{array}{l}\widetilde{\widetilde{g}} \\
\stackrel{\tilde{g}}{\tilde{g}}\end{array}$ & : \\
\hline & 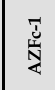 & 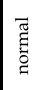 & $\begin{array}{l}\text { 것 } \\
\text { D. } \\
\text { : }\end{array}$ & $\begin{array}{l}\overline{\mathbb{S}} \\
\text { aㅕ }\end{array}$ & 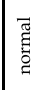 & 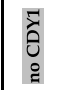 & 受 & 丞 & 㞼 & 丞 & : \\
\hline & त्रे & 丞 & 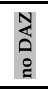 & 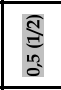 & 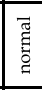 & $\begin{array}{l}\overline{1} \\
\overline{0} \\
0 \\
\vdots\end{array}$ & 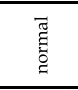 & 㞼 & 呇 & $\begin{array}{l}\overline{\widetilde{g}} \\
\stackrel{\Xi}{\tilde{E}}\end{array}$ & 呇 \\
\hline : & ટ્ર & $N$ & ฐ & $\underset{\mathrm{N}}{\mathbb{N}}$ & 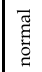 & 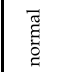 & 丞 & 丞 & 丞 & 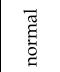 & 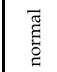 \\
\hline ฮั & $\not{x}$ & ¿ & 눌 & 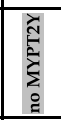 & ब्ञ & 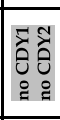 & 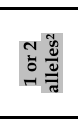 & 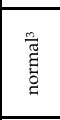 & 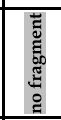 & 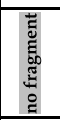 & 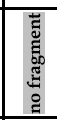 \\
\hline 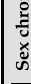 & خ્ર & 12 & 卺 & 慇 & ब্d & 丞 & 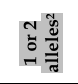 & 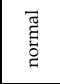 & 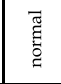 & $\begin{array}{l}\overline{\widetilde{\Xi}} \\
\bar{\Xi}\end{array}$ & 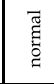 \\
\hline & 咅 & $\underset{\vec{\sigma}}{\overparen{\sigma}}$ & 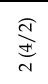 & 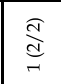 & 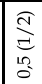 & $\underset{d}{\frac{d}{d}}$ & 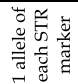 & 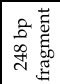 & 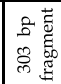 & 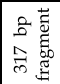 & 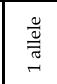 \\
\hline & 亗 & 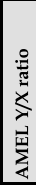 & 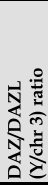 & 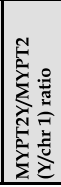 & 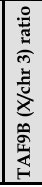 & 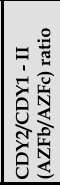 & 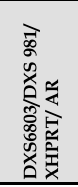 & है & 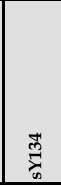 & $\frac{\infty}{6}$ & 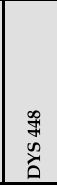 \\
\hline
\end{tabular}

${ }^{1}$ the ratio is slightly higher in heterozygotes and homozygotes for DAZL polymorphism ${ }^{2}$ one allele in homozygotes and two alleles in heterozygotes for particular marker ${ }^{3}$ normal in SRY+ XX males; no fragment in SRY- XX males

Table 2. Results of the 11-plex QF-PCR in normal males and males with sex chromosomal aneuploidies, AZF deletions, partial AZFc deletions and b2/b4 duplication 
normal results in a male DNA samples are presented by a Amel $Y / X$ ratio of 1 , due to the presence of one $X$ and one $Y$ chromosome, DAZ/DAZL ratio of 2, due to the presence of 4 DAZ genes in the AZFc region of $Y$ chromosome and two DAZL genes, one on each chromosome 3. Around $30 \%$ of the samples showed the presence of a $40 \mathrm{bp}$ insertion polymorphism in the DAZL gene in a heterozygous or homozygous state. The DAZ/DAZL ratio was higher in the heterozygotes and homozygotes than in the individuals without this polymorphism due to the area of the $254 \mathrm{bp}$ peak being smaller than the $214 \mathrm{bp}$ peak. The normal MYPT2/MYPT2Y ratio is around 1 due to the presence of two copies of the gene in the $\mathrm{AZFc}$ region of the $\mathrm{Y}$ chromosome and one copy on each of the chromosomes 1, while the normal TAF9B-X/TAF9B-chr 3 ratio is 0,5 due to the presence of two copies of the gene on the chromosomes 3 and one copy on the chromosome $\mathrm{X}$ in males.

The four STR markers on chromosome $X$, as well as the one in the AZFb region on chromosome $Y$ generate one PCR fragment due to the presence of one allele of each of the investigated markers. The non-plymorphic markers on the Y chromosome: SRY, sY134 (in the AZFb region) and sY86 (in the AZFa region) gave PCR fragments of $248 \mathrm{bp}, 303 \mathrm{bp}$ and $317 \mathrm{bp}$ in males without chromosome aneuploidies and/or AZF rearrangements.

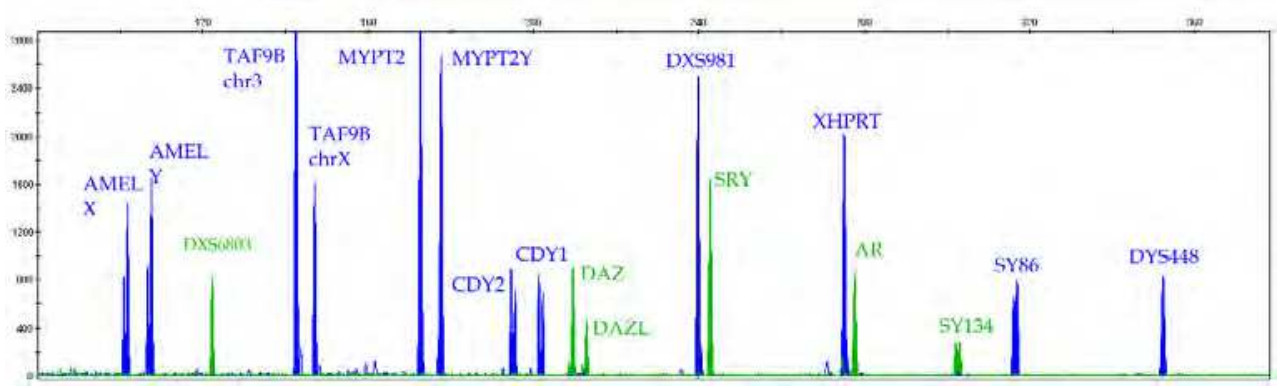

Fig. 3. Electrophoretogram of the 13-plex QF-PCR analysis in a blood sample of normal male.

\subsubsection{QF-PCR results in sex chromosome aneuploidies}

Among the studied males we detected four different chromosome aneuploidies: $X X Y$ or Klinefelter's syndrome $(n=12), X X$ males $(n=2), X Y Y$ males $(n=2)$ and $X Y, X O$ mosaic male $(n=1)$. All $X X Y$ and $X X$ males, as well as one of the two $X Y Y$ men were azoospermic, while the second $X Y Y$ male and the $X Y, X O$ mosaic male presented with severe oligozoospermia. The electrophoreograms of the individuals with sex chromosome aneuploidies are shown in Figures 4-7 and the Y/X, DAZ/DAZL, MYPT2Y/MYPT2 and CDY2/CDY1 ratios are given in Table 2. All detected cases of chromosome aneuploidies were confirmed by cytogenetic analysis.

Klinefelter's syndrome $(X X Y)$ was detected by an abnormal $\mathrm{Y} / \mathrm{X}$ ratio ( 0.5), TAF9B$\mathrm{X} / \mathrm{TAF} 9 \mathrm{~B}-\mathrm{chr} 3$ ratio of $\sim 1$ and presence of two alleles from some of the STR markers on the $\mathrm{X}$ chromosome in a ratio of approximately 1:1 (Figure 4).

The two XX males were characterized by the absence of the $Y$ fragment from the AMEL $Y / X$ marker, DAZ, MYPT2Y, CDY1 and CDY2 fragments and TAF9B-X/TAF9B-chr 3 ratio of $\sim 1$ (Figure 5). In both XX males the SRY fragment was present, sY134, sY86 and DYS 448 fragments were absent and at least one of the four STR markers on the $X$ chromosome 
showed two alleles. Rarely, in XX males the SRY gene is not present in which case the PCR fragment from the SRY gene would be missing and 11-plex QF-PCR pattern would be same as in DNA from normal females.

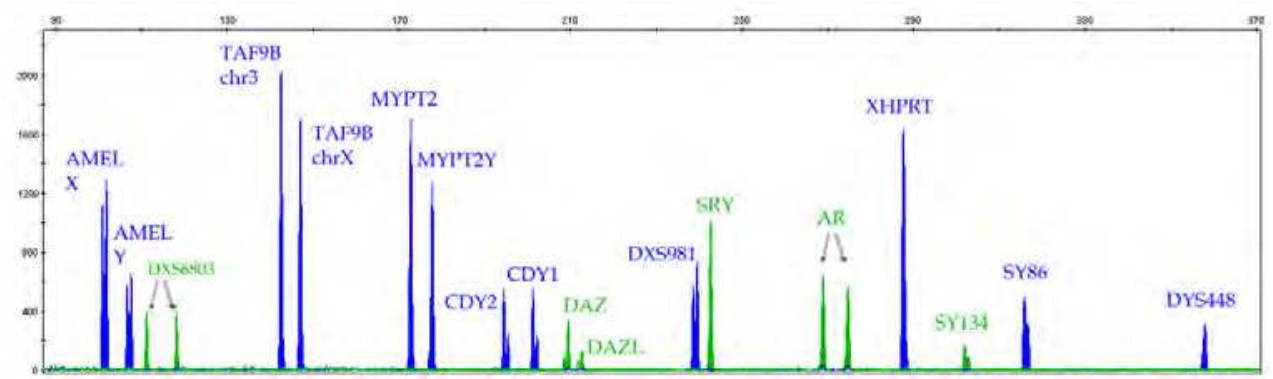

Fig. 4. Electrophoretogram of the 13-plex QF-PCR analysis in a men with Klinefelter's syndrome $(\mathrm{XXY})$.

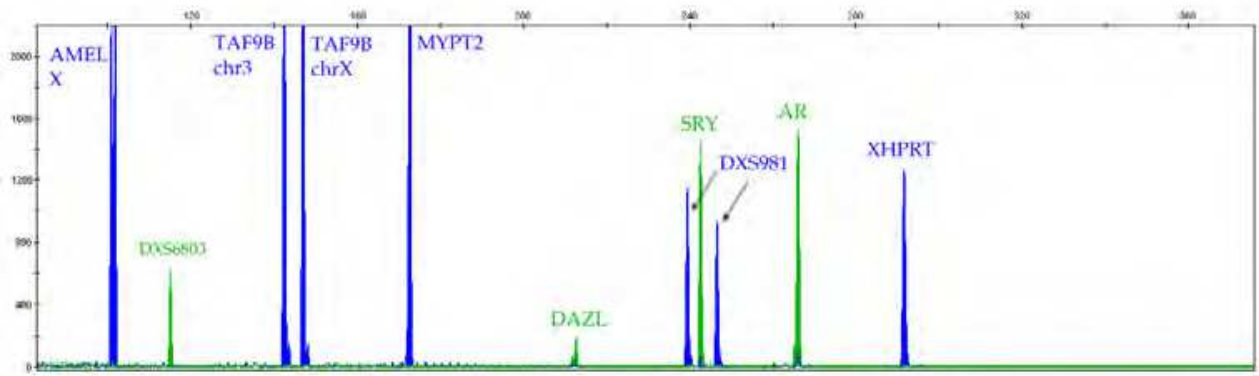

Fig. 5. Electrophoretogram of the 13-plex QF-PCR analysis in a men with XX male syndrome.

The $X Y Y$ individuals showed also a specific pattern, characterized by abnormal $Y / X(\sim 2)$, DAZ/DAZL ( 4) and MYPT2Y/MYPT2 ( 2) ratios, while the TAF9B-X/TAF9B-chr 3 and CDY2/CDY1 ratios were within the normal range (Figure 6).

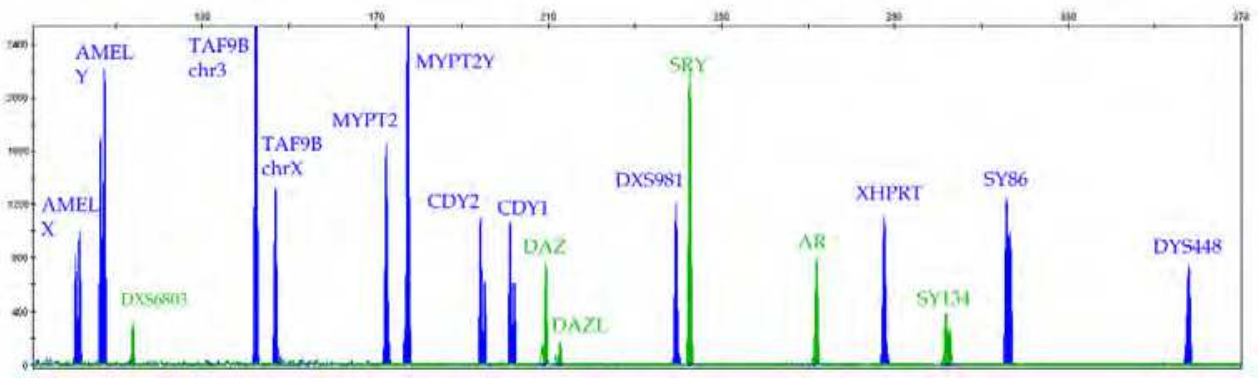

Fig. 6. Electrophoretogram of the 13-plex QF-PCR analysis in a men with XYY syndrome. 
The 13-plex QF-PCR of $X Y, X O$ mosaic male showed abnormal $Y / X(0,35)$ and MYPT2Y/MYPT2 $(0,25)$ and DAZ/DAZL $(0,59)$ ratios, while the CDY2/CDY1 and TAF9B$\mathrm{X} / \mathrm{TAF} 9 \mathrm{~B}-\mathrm{chr} 3$ ratios were normal (Figure 7 ). This result suggested that the $\mathrm{Y}$ chromosome is lost in approximately half of the white blood cells in this patient. The result was confirmed on a DNA isolated from a fresh blood sample and by cytogenetic analysis as well. Analysis of DNA extracted from the buccal swab of this patient showed a normal result. Unfortunately we were not able to analyze DNA isolated from the spermatozoa of this patient.

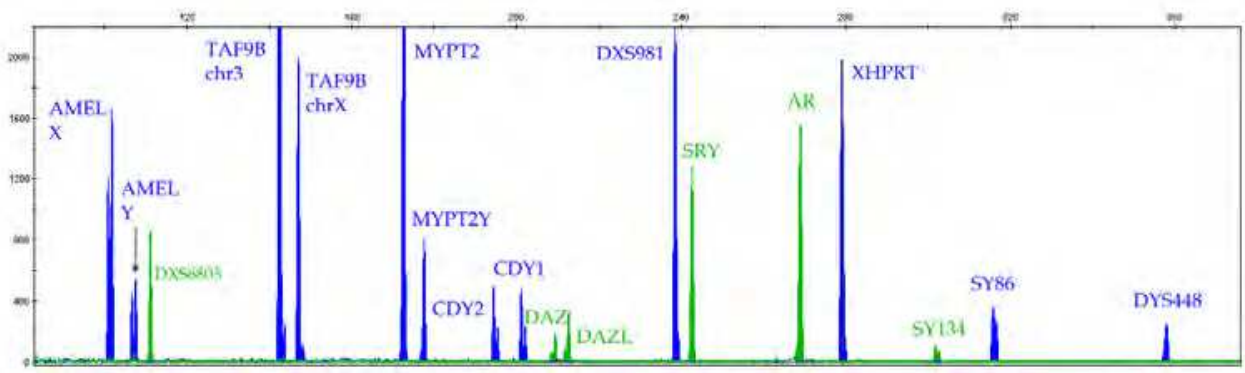

Fig. 7. Electrophoretogram of the 13-plex QF-PCR analysis in a XY/X0 mosaic male.

\subsubsection{QF-PCR results in complete AZF deletions}

During our previous work we have detected eight different AZF deletions, including the two partial AZFc deletions, gr/gr and b2/b3 deletions (Plaseski et al., 2006, Plaseski et al., 2008). Schematic presentation of the deletions is shown in Figure 2.

The 13-plex QF-PCR patterns obtained in the patients with different AZF deletions are given in Table 2. We were able to distinguish all six types of AZF deletions that we detected previously amongst infertile patients (Plaseski et al., 2006). In the six patients with $b 2 / b 4$ deletions the DAZ fragment and the CDY1 fragments were missing, while the MYPT2Y/MYPT2 ratio was decreased suggesting the absence of one of the two MYPT2Y copies on the $\mathrm{Y}$ chromosome. All other fragments showed a normal pattern.

The initial screening for AZF deletions following the guidelines for the detection of $Y$ microdeletions showed presence of AZFc deletions in two other patients (Plaseski et al., 2006). The analysis with additional STS markers showed that in these two patients the $5^{\prime}$ border of the deletion is identical and lies between sY 134 and sY 142 markers. The $3^{\prime}$ border differs and is identical to the $3^{\prime}$ border of the $b 2 / b 4$ deletion in one of the two patients, while in the other it extends distal from the AZFc region (Figure 2). These two patients showed an identical pattern for all markers except for MYPT2Y/MYPT2 (Table 2). In one the MYPT2Y fragment was missing (Figure 8), while in the other it was present, but the ratio of MYPT2Y/MYPT2 was decreased to about half suggesting deletion of one MYPT2Y copy. In both patients markers sY134 in the AZFb region and sY86 in AZFa region were present, while the DYS 448 marker was absent.

During our routine screening for $\mathrm{Y}$ microdeletions we detected one patient with $\mathrm{AZFb}$ deletion. The additional Y STS markers showed that the $5^{\prime}$ border of this deletion is between sY 1228 and sY 1015, while the $3^{\prime}$ border extends in the $5^{\prime}$ part of the AZFc region between sY1291 and sY1191 (Figure 2). This deletion also gave a specific pattern with the 13-plex QF 
PCR characterized by the absence of the DYS 448 and sY134 fragments and ratios of DAZ/DAZL and CDY2/CDY1 markers reduced to half (Table 2), suggesting that two of the four DAZ genes in the AZFc regions and one of the two CDY2 genes in the AZFb region were missing.

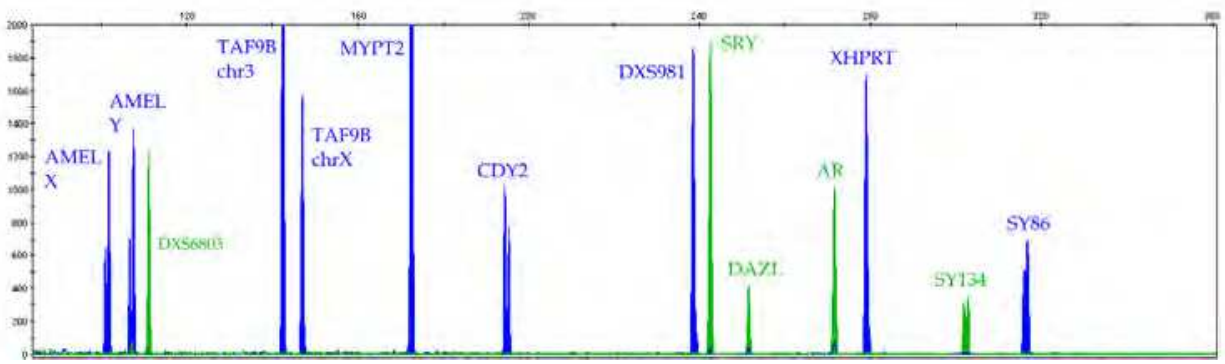

Fig. 8. Electrophoretogram of the 13-plex QF-PCR analysis in a men with AZFc-2 deletion.

The patient with $\mathrm{AZFb}+\mathrm{c}$ deletion also showed a specific pattern with the 13-plex QF-PCR, which was the same as AZFc-1 deletion in all but sY134 marker that was missing and $\mathrm{Y} / \mathrm{X}$ AMEL marker which showed a reduced ratio of 0.23 , due to the presence of $X Y / X 0$ mosaicism (Table 2 and Figure 9). The XY/XO mosaicism was confirmed by cytogenetic analysis.

The QF-PCR result of the AZFa+b+c deletion showed absence of all markers in the AZF a, $\mathrm{b}$ and $\mathrm{c}$ regions (DAZ, MYPT2Y, CDY1, CDY2, sY134, sY86 and DYS448) (Figure 10). The patient with $\mathrm{AZFa}+\mathrm{b}+\mathrm{c}$ deletion also showed an abnormal $\mathrm{Y} / \mathrm{X}$ ratio $(0,42)$, suggesting that the $\mathrm{Y}$ chromosome was lost in half of the cells in this patient.

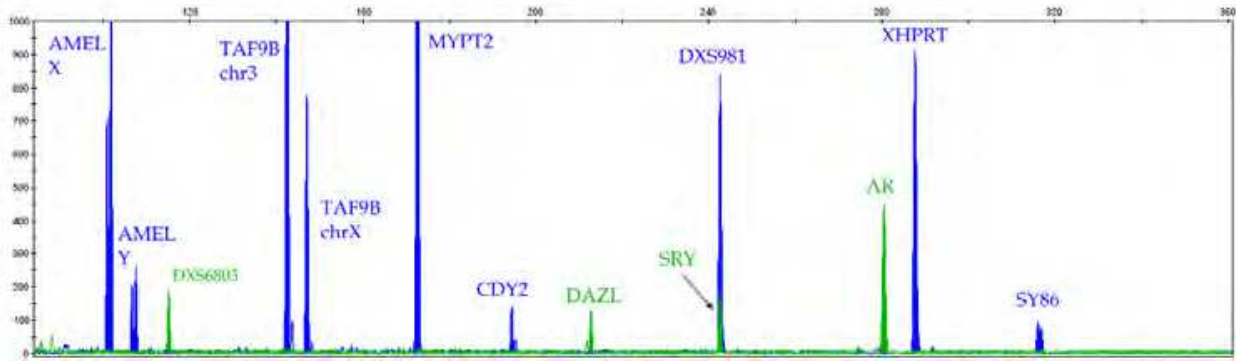

Fig. 9. Electrophoretogram of the 13-plex QF-PCR analysis in a men with $\mathrm{AZFb}+\mathrm{c}$ deletion.

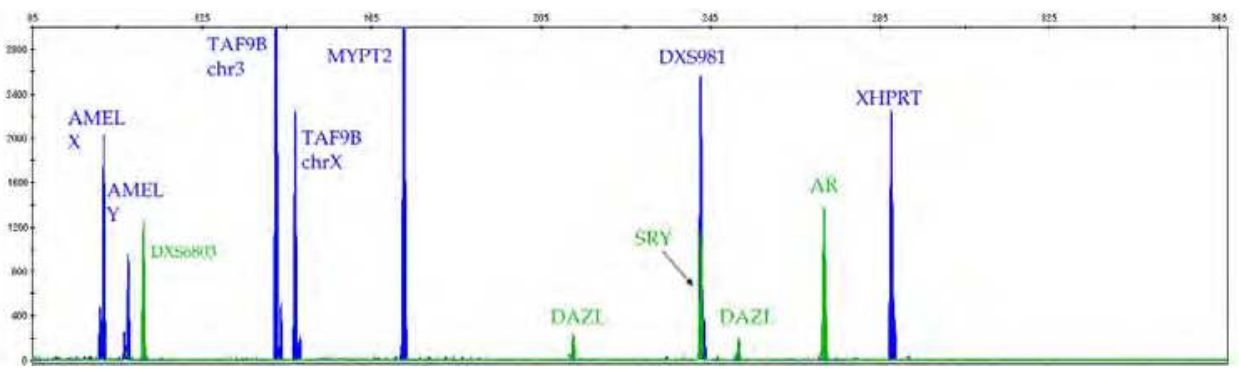

Fig. 10. Electrophoretogram of the 13-plex QF-PCR analysis in a men with AZFa+b+c deletion. 


\subsubsection{QF-PCR results in partial AZFc deletions}

The 13-plex QF-PCR permitted detection of partial AZFc deletions and duplications (Table 2). Both partial AZFc deletions (gr/gr and b2/b3) showed abnormal DAZ/DAZL ( 1) and CDY2/CDY1 ratios ( 2), but differ in the MYPT2Y/MYPT2 ratios which are within the normal range in $\mathrm{b} 2 / \mathrm{b} 3$ deletion and reduced in gr/gr deletion $(\sim 0.5)$. The QF-PCR analysis in men with gr/gr deletion is shown in Figure 11.

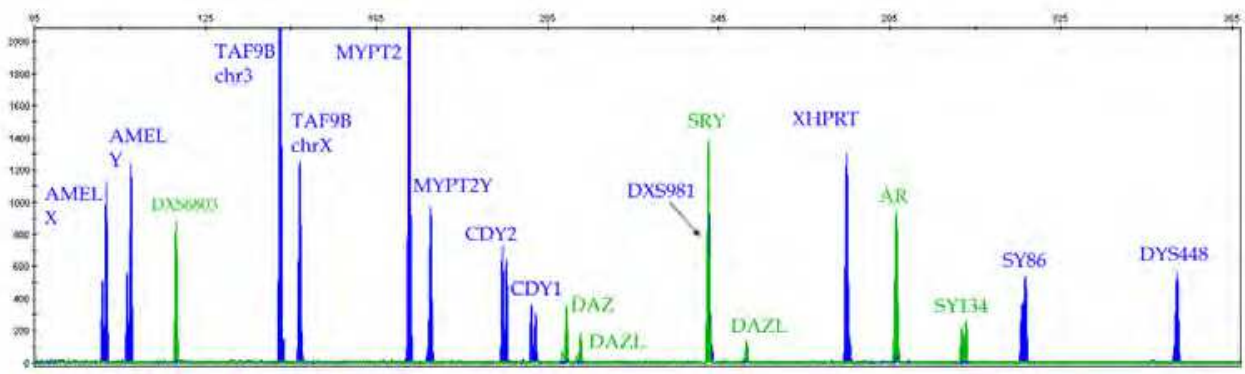

Fig. 11. Electrophoretogram of the 13-plex QF-PCR analysis in a men with gr/gr deletion.

Three of the previously detected patients with gr/gr deletions, showed normal or increased DAZ/DAZL levels, normal, increased or decreased CDY2/CDY1 levels, while the MYPT2Y/MYPT2 ratio was reduced to half, similar to that in the other gr/gr deletions (Figure 12). This rearrangement has probably arisen from gr/gr deletion followed by duplication. All three males with both b2/b4 duplication and gr/gr deletion differ from normal individuals in the MYPT2Y/MYPT2 ratio which is reduced to half.

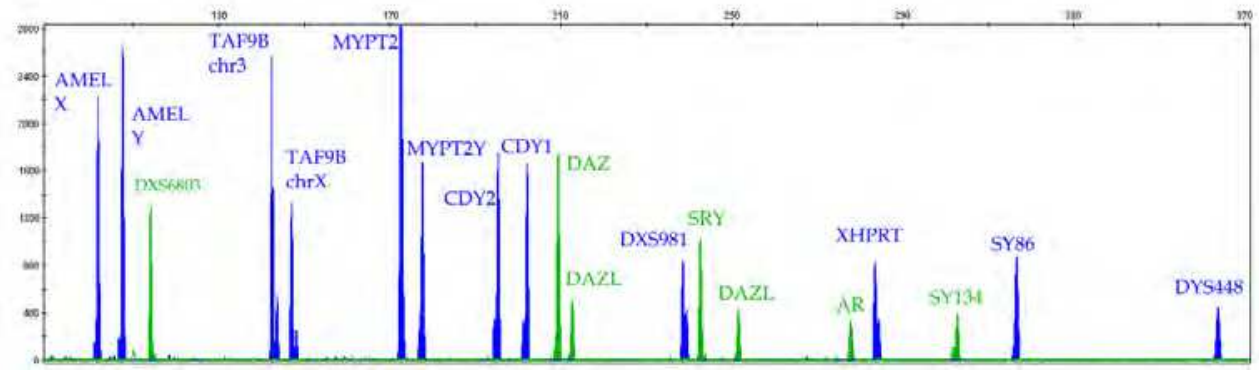

Fig. 12. Electrophoretogram of the 13-plex QF-PCR analysis in a men with b2/b4 duplication and gr/gr deletion.

\subsubsection{QF-PCR results in AZFc duplications}

The 13-plex QF-PCR detected also the duplications mediated by the amplicons in the AZFc region. Samples with gr/gr or b2/b4 duplications were characterized by increased DAZ/DAZL (>3) and MYPT2Y/MYPT2 (>1.5) ratios and decreased CDY2/CDY1 ratios $(<0.5)$ (Table 2). Samples with partial AZFc duplication on chromosomes with $b 2 / b 3$ inversion (b2/b3 duplications), showed increased DAZ/DAZL (>3), normal MYPT2Y/MYPT2 and decreased CDY2/CDY1 ratios (<0.5) (Figure 13). 


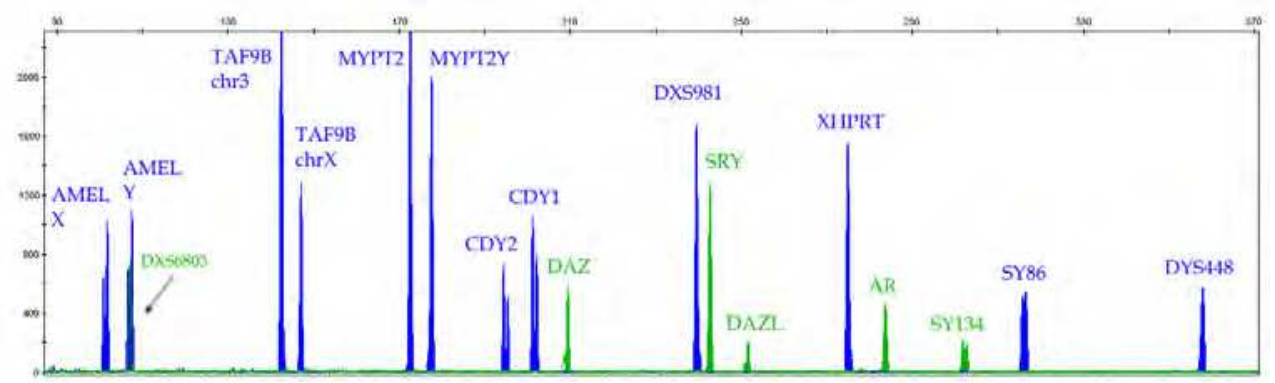

Fig. 12. Electrophoretogram of the 13-plex QF-PCR analysis in a men with b2/b3 duplication.

\subsubsection{Detection of the number of AR CAG repeats}

An additional advantage of our QF-PCR system is that it can also assess the number of the AR CAG repeats, since one of the STR markers on the X chromosome in the 13-plex QF-PCR involves the CAG repeats in the exon 1 of the AR gene. The PCR amplification using oligonucleotide primers surrounding the CAG repeat region in the exon 1 of the AR gene generated fragments with a size ranging from 247 to $309 \mathrm{bp}$, corresponding to the 13 to 34 CAG tandem repeats. The number of CAG repeats predicted by the GeneMapper software v.4.0. (Applied BioSystems) was previously compared with the actual CAG repeats determined by direct dideoxy terminator cycle sequencing using the BigDye Terminator Sequencing Kit v1.0 (Applied BioSystems) in several male DNA samples with 14, 19, 21, 25 and 29 CAG repeats.

\section{Conclusion}

In conclusion, we have developed a rapid, simple, reliable and inexpensive multiplex QFPCR method, that can be used as a first-step genetic analysis in infertile/subfertile men to detect the most common genetic causes of male infertility (sex chromosomal aneuploidies and AZF deletions) and to study some potential risk factors (AZFc partial deletions and duplications and AR CAG repeats).

\section{Acknowledgements}

This study was supported in part by grants CRP/MAC09-01 from ICGEB-Trieste and 141656/1-10 from the Ministry of Education and Science of the R. Macedonia (both to D. Plaseska-Karanfilska).

\section{References}

Carvalho CM, Zuccherato LW, Bastos-Rodrigues L, Santos FR, Pena SD (2006) No association found between gr/gr deletions and infertility in Brazilian males. Mol Hum Reprod 12:269-273. 
Chamberlain NL, Driver ED, Miesfeld RL (1994) The length and location of CAG trinucleotide repeats in the androgen receptor N-terminal domain affect transactivation function. Nucleic Acids Res 22:3181-3186.

Cirigliano V, Lewin P, Szpiro-Tapies S, Fuster C, Adinolfi M (2001) Assessment of new markers for the rapid detection of aneuploidies by quantitative fluorescent PCR (QF-PCR). Ann Hum Genet 65:421-427.

Costa P, Goncalves R, Ferras C, Fernandes S, Fernandes AT, Sousa M, Barros A (2008) Identification of new breakpoints in AZFb and AZFc. Mol Hum Reprod 14:251-8.

De Braekeleer M, Dao TN (1991) Cytogenetic studies in male infertility: a review. Hum Reprod 6:245-250.

de Llanos M, Ballesca JL, Gazquez C, Margarit E, Oliva R (2005) High frequency of gr/gr chromosome $\mathrm{Y}$ deletions in consecutive oligospermic ICSI candidates. Hum Reprod 20:216-220.

Edwards A, Civitello A, Hammond HA, Caskey CT (1991) DNA typing and genetic mapping with trimeric and tetrameric tandem repeats. Am J Hum Genet 49:746-756.

Edwards A, Hammond HA, Jin L, Caskey CT, Chakraborty R (1992) Genetic variation at five trimeric and tetrameric tandem repeat loci in four human population groups. Genomics 12:241-53.

Edwards RG \& Bishop CE (1997) On the origin and frequency of Y chromosome deletions responsible for severe male infertility. Mol Hum Reprod 3: 549-54.

Ferlin A, Moro E, Rossi A, Dallapiccola B, Foresta C (2003) The human Y chromosome's azoospermia factor $\mathrm{b}(\mathrm{AZFb})$ region: sequence, structure, and deletion analysis in infertile men. J Med Genet; 40: 18-24.

Ferlin A, Arredi B, Foresta C (2006) Genetic causes of male infertility. Reprod Toxicol 22:133141.

Ferlin A, Tessari A, Ganz F, Marchina E, Barlati S, Garolla A, Engl B, Foresta C (2005) Association of partial AZFc region deletions with spermatogenic impairment and male infertility. J Med Genet 42:209-213.

Ferlin A, Raicu F, Gatta V, Zuccarello D, Palka G, Foresta C (2007) Male infertility: role of genetic background. Reprod Biomed Online 14:734-45.

Foresta C, Ferlin A, Moro E, Scandellari C (2000) Y chromosome. Lancet 355:234-235.

Foresta C, Garolla A, Bartoloni L, Bettella A, Ferlin A (2005) Genetic abnormalities among severely oligospermic men who are candidates for intracytoplasmic sperm injection. J Clin Endocrinol Metab 90:152-6.

Gekas J, Thepot F, Turleau C, Siffroi JP, Dadoune JP, Briault S, Rio M, Bourouillou G, CarréPigeon F, Wasels R, Benzacken B; Association des Cytogeneticiens de Langue Francaise (2001) Chromosomal factors of infertility in candidate couples for ICSI: an equal risk of constitutional aberrations in women and men. Hum Reprod 16:82-90.

Giachini C, Guarducci E, Longepied G, Degl'Innocenti S, Becherini L, Forti G, Mitchell MJ, Krausz C (2005) The gr/gr deletion(s): a new genetic test in male infertility? J Med Genet 42:497-502.

Hecht F, Hecht B (1987) Aneuploidy in humans: dimensions, demography, and dangers of abnormal numbers of chromosomes. In: Vig BK and Sandberg AA (eds) Aneuploidy: Incidence and Etiology. Alan R. Liss, New York, pp 9-50. 
Hucklenbroich K, Gromoll J, Heinrich M, Hohoff C, Nieschlag E, Simoni M (2005) Partial deletions in the AZFc region of the $\mathrm{Y}$ chromosome occur in men with impaired as well as normal spermatogenesis. Hum Reprod 20:191-197.

Kamp C, Hirschmann P, Voss H, Huellen K, Vogt PH (2000) Two long homologous retroviral sequence blocks in proximal Yq11 cause AZFa microdeletions as a result of intrachromosomal recombination events. Hum Mol Genet 9: 2563-72.

Kleiman SE, Bar-Shira Maymon B, Hauser R, Botchan A, Paz G, Yavetz H, Yogev L (2008) Histone $\mathrm{H} 4$ acetylation and AZFc involvement in germ cells of specimens of impaired spermatogenesis. Fertil Steril 89:1728-36.

Krausz C, Forti G, McElreavey K (2003) The Y chromosome and male fertility and infertility. Int J Androl 26: 70-5.

Kuroda-Kawaguchi T, Skaletsky H, Brown LG, Minx PJ, Cordum HS, Waterston RH, Wilson RK, Silber S, Oates R, Rozen S, Page DC (2001) The AZFc region of the Y chromosome features massive palindromes and uniform recurrent deletions in infertile men. Nat Genet 29:279-286.

Lahn BT and Page DC (1997) Functional coherence of the human Y chromosome. Science 278:675-80.

LaSpada AR, Wilson EM, Lubahn DB, Harding AE, Fishbeck KH (1991) Androgen receptor gene mutations in X-linked spinal and bulbar muscular atrophy. Nature 352: 77-79.

Lardone MC, Parodi DA, Ebensperger M, Peñaloza P, Cornejo V, Valdevenito R, Pommer R, Castro A (2007a) AZFc partial deletions in Chilean men with severe spermatogenic failure. Fertil Steril 88:1318-1326.

Lardone MC, Parodi DA, Valdevenito R, Ebensperger M, Piottante A, Madariaga M, Smith R, Pommer R, Zambrano N, Castro A (2007b) Quantification of DDX3Y, RBMY1, DAZ and TSPY mRNAs in testes of patients with severe impairment of spermatogenesis. Mol Hum Reprod 13:705-12.

Lin YW, Hsu LC, Kuo PL, Huang WJ, Chiang HS, Yeh SD, Hsu TY, Yu YH, Hsiao KN, Cantor RM, Yen PH (2007) Partial duplication at AZFc on the Y chromosome is a risk factor for impaired spermatogenesis in Han Chinese in Taiwan. Hum Mutat 28:486-494.

Ma K, Mallidis C, Bhasin S (2000) The role of Y chromosome deletions in male infertility. Eur J Endocrinol 142:418-430.

Machev N, Saut N, Longepied G, Terriou P, Navarro A, Levy N, Guichaoua M, MetzlerGuillemain C, Collignon P, Frances AM, Belougne J, Clemente E, Chiaroni J, Chevillard C, Durand C, Ducourneau A, Pech N, McElreavey K, Mattei M-G, Mitchell MJ (2004) Sequence family variant loss from the AZFc interval of the human $\mathrm{Y}$ chromosome, but not gene copy loss, is strongly associated with male infertility. J Med Genet 41:814-825.

Mau-Holzmann UA. Somatic chromosomal abnormalities in infertile men and women (2005) Cytogenet Genome Res 111:317-336.

Najmabadi H, Huang V, Yen P, Subbarao MN, Bhasin D, Banaag L, Naseeruddin S, de Kretser DM, Baker HW, McLachlan RI, et al. (1996) Substantial prevalence of microdeletions of the Y-chromosome in infertile men with idiopathic azoospermia 
and oligozoospermia detected using a sequence-tagged site-based mapping strategy. J Clin Endocrinol Metab 81: 1347-52.

Ogilvie CM, Donaghue C, Fox SP, Docherty Z, Mann K (2005) Rapid prenatal diagnosis of aneuploidy using quantitative fluorescence-PCR (QF-PCR). J Histochem Cytochem 53:285-288.

Oliva R, Margarit E, Ballesca JL, Carrio A, Sanchez A, Mila M, Jimenez L, Alvarez-Vijande JR, Ballesta F (1998) Prevalence of Y chromosome microdeletions in oligospermic and azoospermic candidates for intracytoplasmic sperm injection. Fertil Steril 70: 506-10.

Plaseski T, Dimitrovski C, Kocevska B, Efremov GD, Plaseska-Karanfilska D (2003) The prevalence of $\mathrm{Y}$ chromosome microdeletions among infertile males from the Republic of Macedonia. Balkan J Med Genet 6:39-44.

Plaseski T, Noveski P, Kocevska B, Dimitrovski C, Efremov GD and Plaseska-Karanfilska D (2006) AZF deletions in infertile men from the Republic of Macedonia. Prilozi 27:516.

Plaseski T, Noveski P, Trivodalieva S, Efremov GD, Plaseska-Karanfilska D. Detection of sex chromosome aneuploidies and AZF deletions by QF-PCR. Genet Test 12:595-605, 2008.

Ravel C, Chantot-Bastaraud S, El Houate B, Mandelbaum J, Siffroi JP, McElreavey K (2006) GR/GR deletions within the azoospermia factor c region on the $Y$ chromosome might not be associated with spermatogenic failure. Fertil Steril 85:229-231.

Reijo R, Lee TY, Salo P, Alagappan R, Brown LG, Rosenberg M, Rozen S, Jaffe T, Straus D, Hovatta $\mathrm{O}$ et al. (1995) Diverse spermatogenic defects in humans caused by $\mathrm{Y}$ chromosome deletions encompassing a novel RNA-binding protein gene. Nat Genet 10: 383-93.

Repping S, Skaletsky H, Lange J, Silber S, Van der Veen F, Oates RD, Pages DC, Rozen S (2002) Recombination between palindromes P5 and P1 on the human $Y$ chromosome causes massive deletions and spermatogenic failure. Am J Hum Genet 71:906-922.

Repping S, Skaletsky H, Brown L, van Daalen SK, Korver CM, Pyntikova T, KurodaKawaguchi T, de Vries JW, Oates RD, Silber S, van der Veen F, Page DC, Rozen S (2003) Polymorphism for a 1.6-Mb deletion of the human Y chromosome persists through balance between recurrent mutation and haploid selection. Nat Genet 35:247-251.

Repping S, van Daalen SK, Korver CM, Brown LG, Marszalek JD, Gianotten J, Oates RD, Silber S, van der Veen F, Page DC, Rozen S (2004) A family of human Y chromosomes has dispersed throughout northern Eurasia despite a 1.8-Mb deletion in the azoospermia factor c region. Genomics 83:1046-1052.

Reubinoff BE, Abeliovich D,Werner M, Schenker JG, Safran A, LewinA (1998) A birth in non-mosaic Klinefelter's syndrome after testicular fine needle aspiration, intracytoplasmic sperm injection and preimplantation genetic diagnosis. Hum Reprod 13:1887-1892.

Simoni M, Gromoll J, Dworniczak B, Rolf C, Abshagen K, Kamischke A, Carani C, Meschede D, Behre HM, Horst J, Nieschlag E (1997) Screening for deletions of the Y 
chromosome involving the DAZ (Deleted in AZoospermia) gene in azoospermia and severe oligozoospermia. Fertil Steril 67: 542-7.

Simoni M, Kamischke A, Nieschlag E (1998) Current status of the molecular diagnosis of Ychromosomal microdeletions in the work-up of male infertility. Initiative for international quality control. Hum Reprod 13: 1764-8.

Simoni M, Bakker E, Eurlings MC, Matthijs G, Moro E, Muller CR, Vogt PH (1999) Laboratory guidelines for molecular diagnosis of Y-chromosomal microdeletions. Int J Androl 22: 292-9.

Sharara FI (1999) Klinefelter's Syndrome. In: Encyclopaedia of Reproduction. Academic Press, New York, vol 2, pp 938-941.

Skaletsky H, Kuroda-Kawaguchi T, Minx PJ, Cordum HS, Hillier L, Brown LG, Repping S, Pyntikova T, Ali J, Bieri T, Chinwalla A, Delehaunty A, Delehaunty K, Du H, Fewell G, Fulton L, Fulton R, Graves T, Hou SF, Latrielle P, Leonard S, Mardis E, Maupin R, McPherson J, Miner T, Nash W, Nguyen C, Ozersky P, Pepin K, Rock S, Rohlfing T, Scott K, Schultz B, Strong C, Tin-Wollam A, Yang SP, Waterston RH, Wilson RK, Rozen S, Page DC (2003) The male-specific region of the human Y chromosome is a mosaic of discrete sequence classes. Nature 423:825-837.

Skakkebaek NE, Hultén M, Jacobsen P, Mikkelsen M (1973) Quantification of human seminiferous epithelium. II. Histological studies in eight 47,XYY men. J Reprod Fertil 32:391-401.

Sullivan KM, Mannucci A, Kimpton CP, Gill P (1993) A rapid and quantitative DNA sex test: fluorescence-based PCR analysis of X-Y homologous gene amelogenin. Biotechniques 15:636-638.

Tiepolo L \& Zuffardi O (1976) Localization of factors controlling spermatogenesis in the nonfluorescent portion of the human Y chromosome long arm. Hum Genet 34: 11924.

Tilford CA, Kuroda-Kawaguchi T, Skaletsky H, Rozen S, Brown LG, Rosenberg M, McPherson JD, Wylie K, Sekhon M, Kucaba TA et al (2001) A physical map of the human Y chromosome. Nature 409:943-945.

Tut TG, Ghadessy FJ, Trifiro MA, Pinsky L, Yong EL (1997) Long polyglutamine tracts in the androgen receptor are associated with reduced transactivation, impaired sperm production, and male infertility. J Clin Endocrinol Metab 82: 3777-3782.

Vogt PH, Edelmann A, Kirsch S, Henegariu O, Hirschmann P, Kiesewetter F, Kohn FM, Schill WB, Farah S, Ramos C et al (1996) Human Y chromosome azoospermia factors (AZF) mapped to different subregions in Yq11. Hum Mol Genet 5:933-943.

Vogt PH (1998) Human chromosome deletions in Yq11, AZF candidate genes and male infertility: history and update. Mol Hum Reprod 4:739-44.

Vogt PH (2005) AZF deletions and Y chromosomal haplogroups: history and update based on sequence. Hum Reprod Update 11:319-336.

Vollrath D, Foote S, Hilton A, Brown LG, Beer-Romero P, Bogan JS, Page DC (1992) The human Y chromosome: a 43-interval map based on naturally occurring deletions. Science 258: 52-9.

Writzl K, Zorn B, Peterlin B (2005) Copy number of DAZ genes in infertile men. Fertil Steril 84:1522-1525. 
Wu B, Lu NX, Xia YK, Gu AH, Lu CC, Wang W, Song L, Wang SL, Shen HB, Wang XR (2007) A frequent $Y$ chromosome b2/b3 subdeletion shows strong association with male infertility in Han-Chinese population. Hum Reprod 22:1107-1113. 


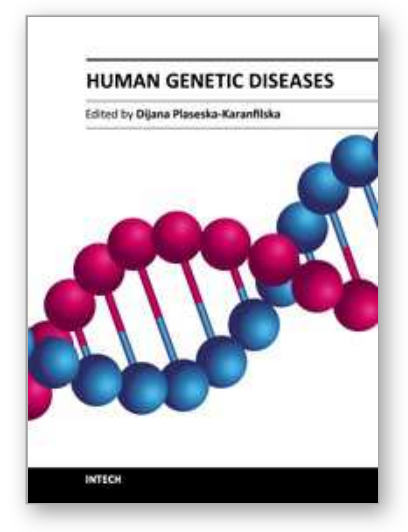

\author{
Human Genetic Diseases \\ Edited by Dr. Dijana Plaseska-Karanfilska
}

ISBN 978-953-307-936-3

Hard cover, 286 pages

Publisher InTech

Published online 30, September, 2011

Published in print edition September, 2011

The genetics science is less than 150 years old, but its accomplishments have been astonishing. Genetics has become an indispensable component of almost all research in modern biology and medicine. Human genetic variation is associated with many, if not all, human diseases and disabilities. Nowadays, studies investigating any biological process, from the molecular level to the population level, use the â€œgenetic approachâ€ to gain understanding of that process. This book contains many diverse chapters, dealing with human genetic diseases, methods to diagnose them, novel approaches to treat them and molecular approaches and concepts to understand them. Although this book does not give a comprehensive overview of human genetic diseases, I believe that the sixteen book chapters will be a valuable resource for researchers and students in different life and medical sciences.

\title{
How to reference
}

In order to correctly reference this scholarly work, feel free to copy and paste the following:

Dijana Plaseska-Karanfilska, Predrag Noveski and Toso Plaseski (2011). Detection of the Most Common Genetic Causes of Male Infertility by Quantitative Fluorescent (QF)-PCR Analysis, Human Genetic Diseases, Dr. Dijana Plaseska-Karanfilska (Ed.), ISBN: 978-953-307-936-3, InTech, Available from:

http://www.intechopen.com/books/human-genetic-diseases/detection-of-the-most-common-genetic-causes-ofmale-infertility-by-quantitative-fluorescent-qf-pcr-a

\section{INTECH}

open science | open minds

\section{InTech Europe}

University Campus STeP Ri

Slavka Krautzeka 83/A

51000 Rijeka, Croatia

Phone: +385 (51) 770447

Fax: +385 (51) 686166

www.intechopen.com

\section{InTech China}

Unit 405, Office Block, Hotel Equatorial Shanghai

No.65, Yan An Road (West), Shanghai, 200040, China

中国上海市延安西路65号上海国际贵都大饭店办公楼 405 单元

Phone: +86-21-62489820

Fax: $+86-21-62489821$ 
(C) 2011 The Author(s). Licensee IntechOpen. This chapter is distributed under the terms of the Creative Commons Attribution-NonCommercialShareAlike-3.0 License, which permits use, distribution and reproduction for non-commercial purposes, provided the original is properly cited and derivative works building on this content are distributed under the same license. 